\title{
SURVEYS FOR GYRFALCONS IN THE SCORESBYSUND REGION OF NORTHEAST GREENLAND IN 1999
}

\author{
Tom J. CAde ${ }^{1}$ and Ólafur K. Nielsen ${ }^{2}$ \\ ${ }^{1}$ The Peregrine Fund, 5668 Flying Hawk Lane, \\ Boise, Idaho 83709,USA. E-mail: tcade@peregrinefund.org \\ ${ }^{2}$ Icelandic Institute of Natural History, Urriðaholtsstrati 6-8, P.O. Box 125,212 \\ Garðabar, Iceland
}

\begin{abstract}
We conducted a helicopter survey over approximately $6,000 \mathrm{~km}^{2}$ of Jameson Land, East Greenland, on 9-10 June 1999 in search of nesting areas for Gyrfalcons (Falco rusticolus). An associate also carried out an overland skiing survey between Scoresbysund village and Selfeldene Peninsula on the Liverpool Coast in the later part of May, returning across the mountains of Liverpool Land to Constable Point. The authors also did a trip in dog-sledges between Scoresbysund village and Cape Höegh on the Liverpool Coast. We found 20 areas that showed signs of current, recent, and historical Gyrfalcon breeding activity, four on the Liverpool Coast and 16 in Jameson Land. Five had confirmed incubating females, seven others had apparent non-breeding pairs $(n=2)$ or single adults present, and three could not be determined because of bad flying conditions. Kap Tobin, located near the entrance of Scoresbysund on its north side, appeared to be a suitable location for a trapping, banding, and marking station for fall migrating Gyrfalcons, and this assumption proved to be correct in 2004 and 2005. Comparing our findings with historical information from the $20^{\text {th }}$ Century, while indicating that there could have been an overall decline of 50 percent in the nesting population of Gyrfalcons in NE Greenland since the mid-1900s, still the current population is substantial, and Scoresbysund remains an important location for studying the migratory movements of falcons along the East Greenland coast and associated marine habitats. Received 9 September 2011, accepted 26 September 2011.
\end{abstract}

CAdE, T. J., AND Ó. K. NIELSEN. 2011. Surveys for Gyrfalcons in the Scoresbysund region of northeast Greenland in 1999. Pages 73-80 in R. T. Watson, T. J. Cade, M. Fuller, G. Hunt, and E. Potapov (Eds.). Gyrfalcons and Ptarmigan in a Changing World, Volume II. The Peregrine Fund, Boise, Idaho, USA. http://dx.doi.org/10.4080/gpcw.2011.0402

Key words: Gyrfalcon, Falco rusticolus, breeding distribution and abundance, migration, Scoresbysund, Greenland.

Ever Since Finn Salomonsen wrote Grønlands Fugle (1950-51) and stated in his account of the Gyrfalcon (Falco rusticolus) that the species "breeds abundantly" in the Scoresbysund region and northward through- out Germania Land ("According to Alw. Pedersen there are about 40 pairs breeding in the interior fjord country and 25 pairs at Liverpool Coast") and also reported that Bang Christensen "observed in the first 18 days of Sept. 
1937 between 200 and 300 white Gyr-Falcons passing Scoresby Sound"-students of the Gyrfalcon have been eager for more information about the occurrence of the bird in this part of Greenland. The general impression from Salomonsen's account has been that NE Greenland is a major center of abundance for the Gyrfalcon, but in more recent decades observers have not been impressed by the number of Gyrfalcons they have encountered there (Meltofte 1975, 1977, Meltofte et al. 1981, Boertmann 1994, Gilg et al. 1997), and a suspicion has emerged that either the Gyrfalcon has declined since the mid-20 $0^{\text {th }}$ Century or the original statements of abundance were exaggerated. For example, in reviewing Alwin Pedersen's original publications from 1926 to 1942 , one finds no indication of how he derived 40 pairs for Scoresbysund and 25 pairs for the Liverpool Coast. He mentioned only one eyrie located on the Neill Klinter formation on the west side of Hurry Fjord just north of Cape Stewart, first reported by E. Bay in 1891-92. Moreover, no one has ever conducted a systematic survey of nesting gyrs anywhere in NE Greenland or done a precise count of fall migrants passing a given location before investigations by The Peregrine Fund (Burnham 2004, 2005).

The purpose of our surveys in 1999 was twofold: first to obtain some idea about the distribution and abundance of nesting Gyrfalcons in the region, and second, to scout for a suitable location to conduct future trapping and banding of fall migrants. Study of topographic maps prior to the trip suggested that Jameson Land would be a suitable place to search for nesting Gyrfalcons because, with adjacent Scoresby Land, it is part of the largest ice-free area in the Scoresbysund region, while the Liverpool Coast, with its numerous headlands and capes and abundant alcid colonies not far from open sea, would make an interesting comparison. Also, Kap Tobin, near the entrance to Scoresbysund on its north shore, appeared topographically to be a likely place where migrating falcons would concentrate or pause temporarily before making an over water passage of some $30 \mathrm{~km}$ across the sound.

\section{ITINERARIES AND METHODS}

Tom Cade and Ólafur K. Nielsen departed from the Reykjavík airport (Iceland) by commercial airline on 9 June 1999 and arrived at Constable Point, northwest shore of Hurry Fjord, Greenland around $1130 \mathrm{~h}$, after an hour's flight. There we met Dany Pierret, a Belgian who has been working on Gyrfalcons with Nielsen in Iceland. Dany had been in Greenland since mid-May and had already searched the Liverpool Coast, traveling on skis from Scoresby Sound Village to the cape opposite Glasgow Island at the mouth of Horsens Fjord $\left(70^{\circ} 48^{\prime} \mathrm{N}\right)$ and then inland across Liverpool Land back to Constable Point. We also met the helicopter pilot, Per Hennings with Air Alpha, and discussed plans for flying during the next few days.

Constable Point is an airfield (large enough for medium-sized commercial jets) and associated facilities that were constructed by ARCO during explorations for oil in the 1980s. It is now operated by the Greenlandic government and has a small "hotel" and a mess hall that are available to travelers and tourists. We arranged for use of these facilities, the helicopter, and the dog-sledges and guides through Nonni Travel in Akureyri, Iceland.

In the evening, Nielsen hiked up to a nearby series of cliffs c. 2-3 km south of camp and found the first Gyrfalcon nest tucked well back behind a projection of rock sticking up from the main face of the cliff; the female was sitting in an old Raven's (Corvus corax) nest. An active Raven nest with young was also nearby. The rock sits above a very long and steep talus and scree slope c. $200 \mathrm{~m}$ high dropping down the west side of Hurry Fjord.

On 10 June-0929-1219 h (2 h 50 min)three observers flew the first helicopter survey with Hennings over the eastern half of Jame- 


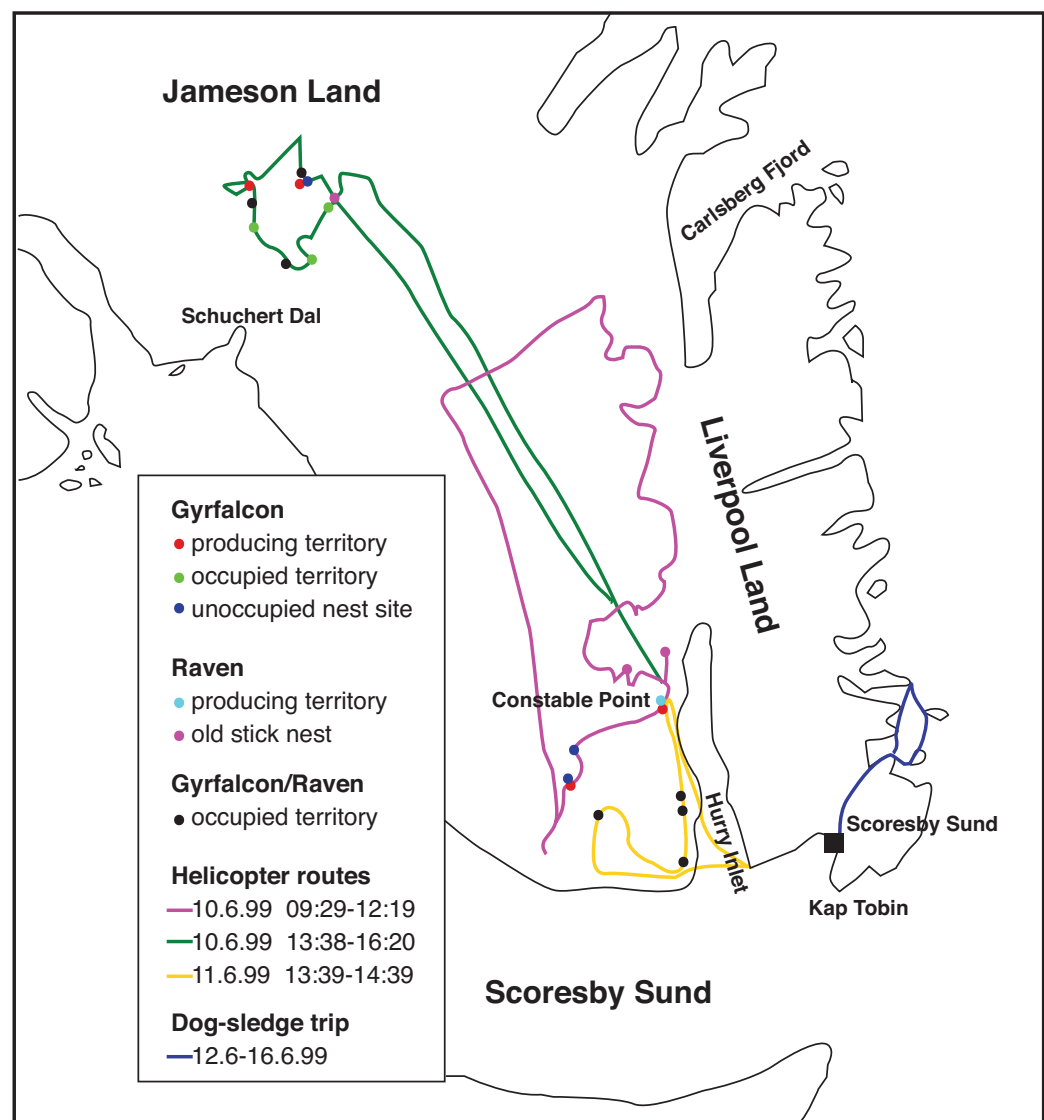

Figure 1. GPS-

determined survey

routes.

son Land, which is mostly high plateau country dissected by numerous small- to mediumsized drainages, some of which cut ravines into the plateau. The terrain generally slopes downward from east to west toward Scoresby Land. These two regions probably comprise about $12,000 \mathrm{~km}^{2}$ to $15,000 \mathrm{~km}^{2}$ of ice-free land and are rich in animal life. The weather was clear and visibility excellent. We flew north along the main drainage flowing into the north end of Hurry Fjord, then southwest over the Jameson plateau to the vicinity of Jakob Severin Berg, then south to Fynselv, and north back to Constable Point, passing the eyrie (female on nest) that Nielsen found the day before (see Figure 1 for route area).

In the afternoon of 10 June $-1338-1620 \mathrm{~h}(2 \mathrm{~h}$ $42 \mathrm{~min}$ ), with weather still good but clouding up in the late afternoon - we deadheaded to the Schuchert Dal, where Per Hennings remem- bered finding three Gyrfalcon nests in the karst formation on the west side of the valley while flying for ARCO in the 1980s. We followed down the Coloradodal NW to a hunters' cabin (built by ARCO) and then SW down Ranunkeldal to Schuchert Dal and across to the Karstryggen, then north to near Korteldal, back across Schuchert Dal, into lower Triaselv, and back to Constable Point (see Figure 1).

On 11 June, our plan was to fly the helicopter down the west side of Hurry Fjord, then over to Kap Tobin and into Scoresby Sound Village (Ittoqqortoormiit) to join our Inuit guides for the dog-sledging trip over to the Liverpool Coast. The weather was overcast with strong, gusty, southerly winds. Cade and Nielsen departed at $1339 \mathrm{~h}$, but unfortunately the wind was too violent to allow us to fly close to the cliffs along Hurry Fjord, and we only got distant views from several hundred meters away; 
even so, we were able to spot three conspicuous holes with fresh whitewash, one being the eyrie that Alwin Pedersen reported. Crossing the fjord to Cape Hope we encountered such strong headwinds that the helicopter was forced to turn back and return to Constable Point (see Figure 1).

On 12 June, Cade and Nielsen traveled by scheduled helicopter to Scoresbysund Village, arriving at $1015 \mathrm{~h}$. We met Ole Brønlund, the Nonni Travel representative, and he introduced us to Isaac and Jonas, our Inuit guides for the sledge trip to the Liverpool Coast. We left the village with two dog teams and sledges at $1330 \mathrm{~h}$ in good weather and traveled over the mountain pass NE to the head of Lillefjord and down the fjord to a hunters' cabin on a point at the mouth where the fjord branches, making about $17 \mathrm{~km}$. These hunters' cabins are spaced apart about one day's travel by dog-sledge all along the Liverpool Coast and northward.

The next morning we traveled about $12-13 \mathrm{~km}$ to Cape Höegh, where we camped at another hunters' cabin near a large colony of Dovekies (Alle alle). [Boertmann in his check-list (1994) estimated there were 3.5 million pairs of Dovekies in colonies along the Liverpool Coast, so there is plenty of summer food for gyrs in this region.] We spent the afternoon and evening in the Dovekie colony, the Inuits shot some birds for dinner, and Nielsen saw a pair of white gyrs on the NE side of the cape, which is virtually an island, connected to the mainland by a very narrow neck of land that is periodically over-washed by the sea. There was no sign of a falcon nest in the immediate vicinity, but there were several good-looking possibilities across the fjord $2-3 \mathrm{~km}$ to the SW.

The next day (14 June) we started our return, stopping along the west side of Rathbone Island to hunt waterfowl and seal. The weather began to deteriorate (NE storm moving in) as we headed on to Raffles Island, where we checked out the murre and fulmar colony on the northeast point. We could not travel along the eastern side owing to rough sea ice stacked up against the shore, and so turned around to find a tenting site on the west side.

The tent was not very substantial or spacious, and around $0300 \mathrm{~h}$ on 15 June it blew down in a gale of c. $80 \mathrm{~km} / \mathrm{h}$. We broke camp in the storm (snow and wind) and traveled about $6 \mathrm{~km}$ in a blinding blizzard back to the hunters' cabin where we had spent the first night. There we waited out the weather all day and into the next. By $0500 \mathrm{~h}$ on 16 June the storm had lessened somewhat, and we returned to Scoresbysund village, arriving there around $0730 \mathrm{~h}$. We finally got the helicopter back to Constable Point at $1630 \mathrm{~h}$ in the afternoon. The big plane had been held up by the storm, and so we got back to Reykjavík after all, around 2000 h. [The plane flies only once a week to Constable Point.]

\section{RESULTS AND DisCUSSION}

Table 1 summarizes our observations on the presence of Gyrfalcons in the region in 1999. We surveyed roughly $6,000 \mathrm{~km}^{2}$ of Jameson Land by helicopter and approximately 40 linear km of the Liverpool Coast by skis in May and dog-sledge in June. We found five active nests (females incubating), one on the coast at the point of Sylfieldene Peninsula opposite Glasgow Island at c. $70^{\circ} 48^{\prime} \mathrm{N}$ and four in Jameson Land. Two of these sites were on cliffs more than $100 \mathrm{~m}$ above the valley floor at the top of long talus and scree slopes, one was on a rock $6 \mathrm{~m}$ above a talus slope facing the sea, and the other two were located in narrow river ravines on rock less than $30 \mathrm{~m}$ above the bottom. Four of the five nests were in deep potholes with an accumulation of whitewash and were close by or within nesting colonies of Barnacle Geese (Branta leucopsis); the other was an old stick nest of the Raven. In addition we saw three, brightly whitewashed holes on the Neill Klinter formation on the west side of Hurry Fjord, all of which had obviously been used in recent years and one or more of which could have been active in 1999. Unfortunately, we could not get close enough to check for 
Table 1. Gyrfalcon observations from helicopter surveys of Jameson Land, East Greenland in 1999.

\begin{tabular}{|c|c|c|}
\hline Day & Time & Notes \\
\hline 09-Jun-99 & $16: 44$ & Harris Mountain: Gyrfalcon nest, incubating bird. Raven nest, with young. \\
\hline 10-Jun-99 & $9: 41$ & Goose Valley, droppings on cliff. \\
\hline 10-Jun-99 & $9: 47$ & Goose Valley, old stick nest (Raven), empty, fresh droppings. \\
\hline 10-Jun-99 & $11: 28$ & Fyn River, fresh droppings on cliff (Raven?). \\
\hline 10-Jun-99 & $11: 39$ & Fyn River, fresh droppings. \\
\hline 10-Jun-99 & $11: 42$ & Fyn River, fresh droppings. \\
\hline 10-Jun-99 & $11: 43$ & Fyn River, fresh droppings, old gyr nest site (cave) with a lot of tradition. \\
\hline 10-Jun-99 & $11: 49$ & Fyn River, Gyrfalcon incubating in a cave, huge mute stain. \\
\hline 10-Jun-99 & $11: 58$ & Fyn River, old gyr nest site, cave/ledge, big mute stain. \\
\hline 10-Jun-99 & $12: 06$ & Harris Mountain, Gyrfalcon nest, bird incubating. \\
\hline 10-Jun-99 & $12: 06$ & Harris Mountain, Raven nest, young. \\
\hline 10-Jun-99 & $12: 10$ & Nathorst Mountain, fresh droppings, old stick nest; gyr reported earlier. \\
\hline 10-Jun-99 & $14: 29$ & Cliff X begins, fresh droppings, lichens, along Ranunkeldal. \\
\hline 10-Jun-99 & $14: 31$ & Cliff $X$ fresh droppings. \\
\hline 10-Jun-99 & $14: 33$ & Cliff X, old stick nest. \\
\hline 10-Jun-99 & $14: 34$ & Cliff X, Gyrfalcon pair on top of cliff. \\
\hline 10-Jun-99 & $14: 38$ & Cliff $X$, fresh droppings. \\
\hline 10-Jun-99 & $14: 47$ & Cliff Y1, isolated cliff, fresh falcon droppings. \\
\hline 10-Jun-99 & $14: 48$ & Cliff Y2, cliff short distance from Y1, Gyrfalcon perched on top, fresh droppings. \\
\hline 10-Jun-99 & $14: 53$ & Mouth Ranunkeldal gorge; droppings on perches, goose nest in old falcon eyrie. \\
\hline 10-Jun-99 & 15:00 & Karst Ridge, fresh droppings, huge cliffs, gyr perched on top of cliff. \\
\hline 10-Jun-99 & 15:08 & Karst Ridge, old traditional roost site (huge amount of droppings). \\
\hline 10-Jun-99 & $15: 12$ & Karst Ridge, Gyrfalcon incubating 4 eggs in cave. \\
\hline 10-Jun-99 & $15: 29$ & Gorge, short, left limit of Schuchert; cave with a big mute stain, not checked. \\
\hline 10-Jun-99 & 15:32 & Triaselv gorge, Gyrfalcon incubating in cave. \\
\hline 10-Jun-99 & 15:33 & Triaselv gorge, old nest site. \\
\hline 11-Jun-99 & $13: 54$ & Neill Klinter, bright shining mute stain from hole, possibly active nest. \\
\hline 11-Jun-99 & 13:55 & Neill Klinter, bright shining mute stain from hole, possibly active nest. \\
\hline 11-Jun-99 & $13: 58$ & Neill Klinter, isolated cliff just south of main cliff face, possibly active nest. \\
\hline 11-Jun-99 & 14:07 & Muslingselv, isolated cliff, cave with a huge mute stain. \\
\hline
\end{tabular}

incubating birds. Seven other locales had pairs $(n=2)$ or single birds present near obviously used Gyrfalcon eyries, and five other locales with used nest sites were found with no birds seen. Four of these gyr territories were on the Liverpool Coast, and 16 were in Jameson Land. All of the Gyrfalcons we saw were in the range of white variants.

\section{Conclusion}

Based on these observations and on the ecophysiographic features of the region, we believe that there could well have been 30 or more gyr nesting territories in Jameson Land and adjacent parts of Scoresby Land north approximately to $71^{\circ} 45^{\prime} \mathrm{N}$, in a region of some $12,000 \mathrm{~km}^{2}$ to $15,000 \mathrm{~km}^{2}$. Of the 16 actual or potential areas discovered in Jameson Land, seven $(44 \%)$ had falcons present and four $(25 \%)$, or possibly five to six $(37 \%)$ had nesting birds. How many of these sites could be occupied in a given year is problematic, but would certainly depend on the abundance of prey in the region. For example, in a ptarmigan-rich region of NE Iceland, falcon occu- 
pancy of 82 known territories ranged from 39 $(47.6 \%)$ in a low ptarmigan year to $63(76.8 \%)$ in a high year for the years 1981-2000 (Nielsen 2003). In West Greenland, where ptarmigan are less abundant and more variable in their annual numbers than in Iceland, samples of known nesting areas ranging from 12 to 71 had occupancy rates ranging from 0 (twice) to $41 \%$, but generally between $10 \%$ and $25 \%$ over the period 1985 to 2005 (Burnham 2007).

We did not have an opportunity to survey the west side of Carlsberg Fjord or any of the valleys north of $70^{\circ} 30^{\prime} \mathrm{N}$, all of which appear topographically suitable for nesting gyrs. Nor did we examine the Schuchert Dal completely. This is an area of considerable interest, as in a good food year it might be possible to study 6 to 8 nesting pairs in an area of c. $750 \mathrm{~km}^{2}$. Moreover, there is a good cabin located within $10 \mathrm{~km}$ of the area.

We did not survey the stream beds flowing out of the Jameson plateau on its western edge. Observations of nesting sites on the Fenselv, Muslingselv, and Ranunkeldal indicate that some of these drainages may have shallow ravines with suitable rock for falcons. These sites are not easily seen from a helicopter until one is directly over them.

Another area of potential interest for further study is the western shore of Hurry Fjord and the inland plateau country immediately westward. Again, in an area of c. $940 \mathrm{~km}^{2}$ in a good year one might find 8 to 10 active nests, working out of Constable Point. In addition to the areas we identified, Isaac and Jonas told us that they once found a gyr nest on a mound in flat tundra west of Neill Klinter. Such sites - similar to Snowy Owl (Bubo scandiacus) nest mounds - are not known in other parts of the gyr's range. It should be further noted that all of Jameson Land is readily accessible by cross-country skis or dogsledge before spring breakup and, after breakup and runoff, on foot, as the plateau does not contain much boggy or marshy ground. All-terrain vehicles could also be used.
We may have encountered a post-peak breeding population of gyrs in 1999, as prey species were not abundant. We only saw ptarmigan in four locations, hare three times, and lemmings had apparently crashed in 1998, according to the local people at Constable Point. We saw a couple of lemmings scurrying around the buildings at Constable Point as the snow was melting off the surrounding tundra. We also found only one pair of nesting Ravens. Shorebirds and waterfowl, on the other hand, were numerous, especially Barnacle and Pink-footed Geese (Anser brachyrhynchus), which Gyrfalcons sometimes eat. Jameson Land and Scoresby Land, in general, appear to be biotically rich areas, and they should be optimal habitat in good years for both ptarmigan and Collared Lemmings (Dicrostonyx groenlandicus).

The Liverpool Coast is rather different from Jameson Land. Here fjords, headlands, and capes with medium to high cliffs dominate the landscape, and Dovekies and other seabirds are abundant along the outer coast. We obtained information on the occurrence of Gyrfalcons at four locations-Raffles Island, Rathbone Island, Cape Höegh, and the cape at the mouth of Horsens Fjord (opposite Glasgow Island) each separated from its nearest neighbor by $7-$ $10 \mathrm{~km}$. It appears that the gyrs in this region prefer the offshore islets and headlands facing the sea rather than the interior fjords, which head into glaciers. The Dovekies and other seabirds also prefer the outer coast for locating their nesting colonies, probably because they are closer to the open sea areas where they feed. Based on these considerations and on what the map tells us about the frequency and distribution of islets and capes north to Carlsberg Fjord (more than $200 \mathrm{~km}$ of shoreline), we think it is entirely possible that there were about 20 nesting territories along the Liverpool Coast. Again, how many may be occupied in a given year is a question that only extensive field research can answer, but we doubt that the occupancy rate in recent decades has been more than about 30 percent. 
The interior of Liverpool Land is extensively covered by glaciers, and our impression of the west side, looking east from Hurry Fjord in the helicopter, was that it remains frozen and inhospitable for a much longer time than either the coast of Jameson Land and much of Scoresby Land. The same applies to the interior fjords of Scoresbysund; in June, while we were there, ice still completely covered Scoresbysound down to within a few kilometers of Hurry Fjord, even though the season was earlier than usual. We think it is unlikely that many gyrs nest in the fjords dominated by glaciers. Even though suitable nesting sites occur in such situations, the prey base may be too sparse to support breeding. Admittedly, however, we did not spend much time searching this type of landscape. The existence of a permanent polynya at the mouth of Scoresbysund provides winter habitat for marine mammals and birds, as do half a dozen or so smaller polynyas located farther into the sound (Sandell and Sandell 1991). All these features make for interesting habitat possibilities for Gyrfalcons. Another location that needs to be checked for falcons is the extensive wall of basaltic rocks and talus facing the ocean immediately south of the entrance into Scoresbysund.

Unfortunately we were unable to examine Kap Tobin closely from the air or on the ground. We did get a view of it from a distance (c. $10 \mathrm{~km})$ as we landed in the helicopter at Ittoqqortoormiit, and we obtained some information from Ole Brønlund and the Inuit. The peninsula leading out to Kap Tobin is flat and low lying for several kilometers in all directions, except for a conspicuous, pingo-like, rounded hill a few kilometers inland from the cape itself. This hill provides an open, $360^{\circ}$ view of the entire area and might well make a very suitable trapping station, as any falcon flying within a few kilometers of it would be likely to see a moving bait-bird. It is about $1 \mathrm{~km}$ from a small settlement of 8 to 10 Inuit who live near the cape in winter. There are vacant cabins that could be rented there; Nonni Travel owns one that it rents to occasional tourists. Furthermore, the old
Danish weather station was located nearby, and it probably was there where Bang Christensen made his observations in 1937 and where most of the 250 Gyrfalcons that Pedersen refers to were shot in the fall of 1928. According to Ole Brønlund and the Inuit, gyrs are still frequently seen around Kap Tobin in the fall- "up to five at one time fighting with Ravens." They occur from early September into November but mainly from mid-September to mid-October in most years, according to Brønlund.

It seems likely that a trapping and banding station located at Kap Tobin would intercept a large portion of the migrating Gyrfalcons that come down out of NE Greenland in the fall. Is it still possible to see a passage of 200-300 falcons in a two-week period?

In terms of cost effectiveness, the operation of such a station over several years would probably yield more new information and results on the gyrs of East Greenland, especially with satellite radio-tracking, than would breeding season studies of widely dispersed nesting Gyrfalcons.

In 2004 and 2005, The Peregrine Fund sent teams of trappers and banders to Kap Tobin, Scoresbysund to explore some of these possibilities (Burnham 2004, 2005, Burnham and Newton 2011). From 17 September to 25 October 2004, three investigators carried out the first systematic trapping there on the Boscoe Berge Peninsula near the Kap Tobin village (Figure 2). Despite quite a bit of bad weather, they trapped for 35 days ( 252 hours), capturing 32 gyrs, averaging 7.2 hours of trapping per day and 7.88 hours per gyr. They also caught one Snowy Owl and four Ravens. In 2005, the same three workers trapped from mid-September to 17 October for a total of 379.5 hours, capturing a total of 87 gyrs or one gyr per 4.41 hours (81 hatch-year, 1 immature) and 1 immature male Peregrine (Falco peregrinus).

Although we do not know how many Gyrfalcons were nesting in Northeast Greenland in 


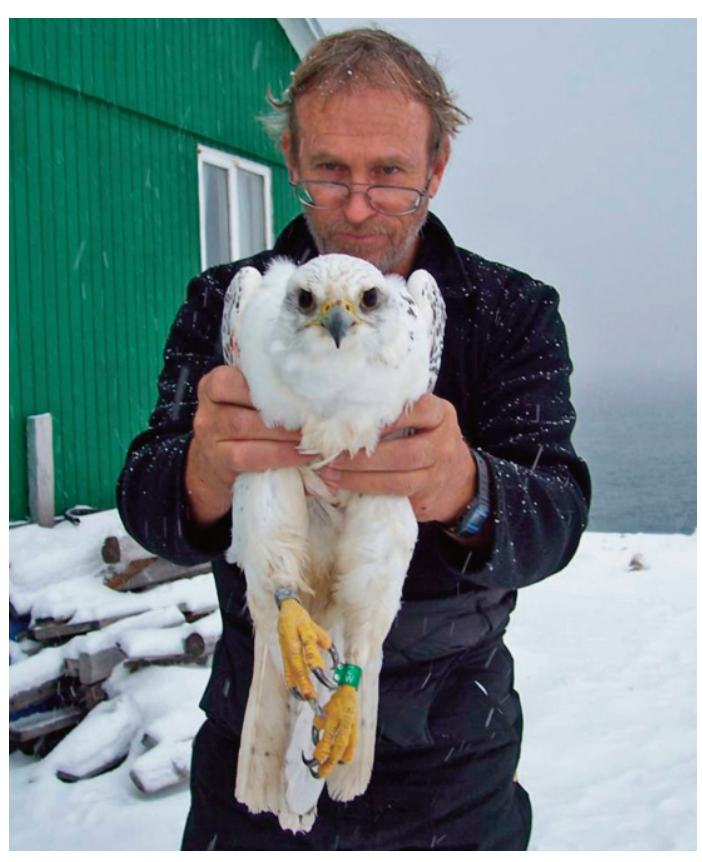

Figure 2. Jim Willmarth banded this very large female gyr while trapping for The Peregrine Fund study in 2004 near Kap Tobin.

those years or what the abundance of their prey was, the difference in number of migrants trapped in 2004 and 2005 and their absolute numbers indicate that a sizeable but fluctuating population of Gyrfalcons still breeds in the region.

\section{Literature Cited}

BoERTMANN, D. 1994. An annotated checklist to the birds of Greenland. Medelelser om Grønland Bioscience 38:1-63.

Burnham, K. K. 2004. The Peregrine Fund Arctic Program. Progress Report 2004. The Peregrine Fund, Boise, Idaho, USA.

Burnham, K. K. 2005. The Peregrine Fund Arctic Program. Progress Report 2005. The Peregrine Fund, Boise, Idaho, USA.

BURNHAM, K. K. 2007. Inter- and intraspecific variation of breeding biology, movements, and genotype in Peregrine Falcon Falco peregrinus and Gyrfalcon F. rusticolus pop- ulations in Greenland. Doctoral Dissertation. Wolfson College, University of Oxford, Oxford, UK.

Burnham, K. K., AND I. Newton. 2011. Seasonal movements of Gyrfalcons Falco rusticolus include extensive periods at sea. Ibis 153:468-484.

Gilg, O., B. Sittler, ANd B. SABARd. 1997. Numerical and functional response of Gyrfalcon (Falco rusticolus) to lemming (Dicrostonyx groenlandicus) fluctuations in NE Greenland. Pages 5-6 in T. B. Berg, M. C. Forchhammer, and E. Skytte (Eds.). Arktisk Biologisk Forskermode VI. Danish Polar Center, Copenhagen, Denmark.

Meltofte, H. 1975. Ornithological observations in northeast Greenland between $76^{\circ} 00^{\prime}$ and $78^{\circ} 00^{\prime}$ N. lat., 1969-71. Meddelelser om Grønland, Bioscience 191(9): $1-72$.

Meltofte, H. 1977. Ornithological observations in Germania Land, Northeast Greenland, 1975. Dansk Ornithologisk Forenings Tidsskrift 71:81-94.

Meltofte, H., M. Elander, and C. HJort. 1981. Ornithological observations in northeast Greenland between $74^{\circ} 30^{\prime}$ and $76^{\circ} 00^{\prime}$ N. lat., 1976. Meddelelser om Grønland, Bioscience 3:1-53.

NiELSEN, Ó. K. 2003. The impact of food availability on Gyrfalcon (Falco rusticolus) diet and timing of breeding. In D. B. A. Thompson, S. M. Redpath, A. H. Fielding, M. Marquiss, and C.A.Galbraith (Eds.). Birds of Prey in a Changing Environment. Scottish Natural Heritage. The Stationery Office, Ltd, Edinburgh, Scotland, UK.

SAlomonsen, F. 1950-51. Grønlands Fugle. The Birds of Greenland. 3 parts. Munksgaard, Copenhagen, Denmark.

SAndell, H. T., AND B. SANDell. 1991. Archaeology and environment in the Scoresby Sound fjord: Ethno-archaeological investigations of the last Thule Culture of Northeast Greenland. Medelelser om Grønland: Man and Society 15: 1-150. 